\title{
Performance characteristics and meat quality assessment of guinea fowl fed varied
} levels of dietary protein

${ }^{1}$ Rafiu T. A., ${ }^{2}$ Adetutu O. I., ${ }^{1}$ Adesoye F. A., ${ }^{1}$ Adeniji O. J. and ${ }^{1}$ Oluwafemi E. O.

${ }^{1}$ Department of Animal Production and Health,

Ladoke Akintola University of Technology, P.M.B. 4000, Ogbomoso, Nigeria.

${ }^{2}$ Department of Animal Production Technology,

Federal College of Agriculture, P.M.B. 7008, Ishiagu, Nigeria

Abstract

Corresponding author: tarafiu@lautech.edu.ng; 08168662151

Guinea fowl appears to be a promising poultry meat source but its production strength under most common extensive or semi-intensive impair the potentials, this work therefore was done to investigate the dietary protein requirement of 10 weeks old Guinea fowl fed exclusively with compounded feed under intensive system. It was conducted at the poultry unit of Teaching and Research Farm unit of Ladoke Akintola University of Technology, Ogbomoso and lasted for a period of 16 weeks. A total number of 120 growing guinea fowl birds were used for the experiment; they were equally and randomly distributed to four dietary treatments of three replicates per group with ten birds per replicate, they were randomly allocated to diets 1, 2, 3 and 4 which contained 16\%, 18\%, 20\% and 22\% crude protein respectively. Weekly weight gain, feed intake and feed conversion ratio were monitored. At the end of 15 weeks, two birds per replicate were randomly picked, housed in metabolic cage and their feacal samples were collected for nutrient analysis and digestibility study, blood samples were collected from same sampled birds for hematological characteristics, so also their meat samples for meat quality analysis. Highest final weight (1555.99g) was recorded from $18 \%$ followed by $20 \%$ (1517.55g) while the least final weight was recorded from $22 \%$ (1482.72g). The highest and least daily feed intake was recorded from $22 \%(99.53 \mathrm{~g})$ and $16 \%$ $(86.37 g)$ respectively. There were significant $(P<0.05)$ differences in the birds' nutrient digestibility except for ash. Significantly $(P<0.05)$ high value of $W B C\left(19.53 \times 10^{3} / \mathrm{mm}^{3}\right)$ was observed in $20 \%$ compared to $16.98 \times 10^{3} / \mathrm{mm}^{3}, 12.65 \times 10^{3} / \mathrm{mm}^{3}, 10.83 \times 10^{3} / \mathrm{mm}^{3}$ from $16 \%$, $18 \%, 22 \%$ respectively, while the differential counts (\%) of monocytes, lymphocytes, heterophil, basophil obtained were not significantly $(P>0.05)$ influenced. Crude protein content of the thigh and breast muscle increased $(P<0.05)$ while the crude fat decreased with increased dietary protein while no significant $(P>0.05)$ difference was observed in the values recorded for ash. Hence for better performance, 18\% dietary protein should be fed considerably in the diet of growing guinea fowl.

Keywords: Guinea fowl, dietary protein, blood, meat quality

Caractéristiques de la performance et évaluation de la qualité de la viande d'une volaille Guinée Niveaux variés de protéines diététiques

\section{Résumé}

La volaille de Guinée semble être une source de viande de volaille prometteuse, mais sa résistance à la production sous tension étendue ou semi-intensif la plus fréquentée les potentiels, ce travail a donc été fait pour enquêter sur l'exigence de protéines alimentaires de 10 semaines de de poule de Guinée nourri exclusivement avec des aliments intensifs système. Elle a été réalisée à l'unité avicole de l'unité Ferme d'enseignement et de recherche de Ladoke Akintola, University of Technology Ogbomoso et a duré une période de 16 semaines. 


\section{Performance characteristics and meat quality assessment of guinea fowl}

Un nombre total de 120 oiseaux à croissance de Guinée de croissance ont été utilisés pour l'expérience; Ils étaient également distribués de manière aléatoire et aléatoirement à quatre traitements diététiques de trois répliquant par groupe avec dix oiseaux par réplication, ils ont été alloués de manière aléatoire aux régimes 1, 2, 3 et 4 qui contenaient respectivement $16 \%, 18 \%, 20 \%$ et 22\% de protéines brutes de brut respectivement. Le gain de poids hebdomadaire, l'apport d'alimentation et le rapport de conversion d'alimentation ont été surveillés. À la fin de 15 semaines, deux oiseaux par réplication ont été cueillis au hasard, hébergés dans une cage métabolique et leurs échantillons fantascaux ont été collectés pour l'analyse des éléments nutritifs et l'étude de digestibilité, des échantillons de sang ont été collectés à partir de mêmes oiseaux échantillonnés pour les caractéristiques hématologiques, ainsi que leurs échantillons de viande pour Analyse de la qualité de la viande. Le poids final le plus élevé (1555,99 g) a été enregistré de $18 \%$ suivi de 20\% $(1517,55 \mathrm{~g})$ tandis que le poids le moins final a été enregistré de 22\% $(1482,72 \mathrm{~g})$. L'apport alimentaire le plus élevé et le moins quotidien a été comptabilisé de 22\% (99.53 g) et de 16\% $(86,37 \mathrm{~g})$ respectivement. Il y avait des différences significatives $(p<0,05)$ dans la digestibilité des nutriments des oiseaux, à l'exception des cendres. Significativement ( $p$ $<0,05)$ haute valeur de $\operatorname{WBC}(19,53 \times 103 / \mathrm{mm} 3)$ a été observée dans $20 \%$ par rapport à 16,98 $x \mathrm{l03} / \mathrm{mm} 3,12,65 \times 103 / \mathrm{mm} 3,10,83 \times 103 / \mathrm{mm} 3$ de 16\%, 18\%, 22\% respectivement, tandis que la Les comptes différentiels (\%) des monocytes, des lymphocytes, hétérophiles, basophile obtenus n'étaient pas significativement ( $p>0,05)$ influencés. La teneur en protéines brut de la cuisse et du muscle du sein a augmenté $(p<0,05)$ tandis que la graisse brute a diminué avec une protéine alimentaire accrue, sans aucune différence significative $(p>0,05)$ n'a été observée dans les valeurs enregistrées pour les cendres. Par conséquent, pour une meilleure performance, une protéine diététique de $18 \%$ devrait être considérablement nourrie dans le régime alimentaire de la grosseur de la poule en guinée.

Mots-clés: Poule de guinée, Protéines diététiques, sang, qualité de la viande

\section{Introduction}

Guinea fowl are thought to have originated in Africa; its production has increased rapidly throughout the entire world. Guinea fowl can be successfully reared under semiintensive conditions with less effort. Hence, it has been given importance as an alternative poultry (Sarica et al., 2003). It is also identified as a good chance of recovery of the animal protein due to nutritional and dietary outstanding of its meat and eggs (Agwunobi and Elpenyong, 1991). However, this rearing under semi-intensive system hinders its availability in abundant and makes it less known to the populace and difficult to perfectly contribute to poultry meat production. Advancement to intensive mode of management is going to further express its importance but presently in Nigeria there is no commercially compounded feed tagged guinea fowl feed like that of broiler and other common poultry birds. The birds are allowed to scavenge for most of their food and supplemented with broiler feed, where raised under semi-intensive system. Dahouda et al. (2017) reported that guinea fowl keepers did not practice any rationale feeding system for their birds. It was observed that in addition to scavenging most of the farmers provided small amounts of supplementary feed to their birds (Gono et al., 2012). Probably because there were no specific formulated rations for domesticated guinea fowl (Moreki and Seabo, 2012). Thus, farmers resorted to feeding their guinea fowls with commercial broiler chicken and layer chicken diets, with cereal grains and green vegetables as supplementary feeds (Dahouda et al., 
2017). Adeyemo et al. (2006) recommended $16 \%$ dietary protein for the growing guinea fowl and maintained until they come to lay at 152-day old, while Ayeni (1980) recommended a protein concentration of $18-20 \%$ to be appropriate for the growing stage. In free range system, the author recommended a protein concentration of $16 \%$ for adult birds with supplementary feeding on green vegetable matter and insects. On the other hand, diets containing amino acid as supplement are ineffective in terms of excessive protein consumption. It has not been clarified yet whether high level of methionine is especially needed by Guinea fowl fed by a mixture of feed of 15.5 and 19.5\% CP. Another proved fact is that the amount of mortality increases in relation to the increasing content of protein in diets (Le Coz- Douin, 1992). Intensive management of guinea fowl who dependen solely on concentrate without supplement of any form or access to feed on green vegetable like that of semi-intensive will therefore demand more nutrients in order to produce optimally. Hence, increased proportion of dietary crude protein among other vital nutrients was investigated.

\section{Materials and methods Experimental site}

The experiment was conducted at the poultry unit of Teaching and Research Farm of Ladoke Akintola University of Technology, Ogbomoso, Oyo state, Nigeria.

\section{Experimental birds and management}

A total number of one hundred and twenty (120) ten weeks old, growing guinea fowl were used for the experiment; they were equally and randomly distributed to the four dietary treatments. Each treatment group was sub divided into three replicates of 10 birds per replicate. Feed and water were supplied regularly and vaccination program was done as at when due. Four experimental diets were formulated such that diet 1,2, 3 and 4 containing 16,18, 20 and $22 \%$ crude protein respectively (Table 1).

Table 1: Composition of experimental diets with different dietary levels of crude protein

\begin{tabular}{lllll}
\hline Ingredients $(\mathbf{\%})$ & $\mathbf{T}_{\mathbf{1}}(\mathbf{1 6 \%} \mathbf{C P})$ & $\mathbf{T}_{\mathbf{2}} \mathbf{( 1 8 \% \mathbf { C P } )}$ & $\mathbf{T}_{\mathbf{3}}(\mathbf{2 0} \mathbf{0} \mathbf{C P})$ & $\mathbf{T}_{\mathbf{4}}(\mathbf{2 2 \%} \mathbf{0} \mathbf{)})$ \\
\hline Maize & 50.2 & 48.0 & 45.0 & 43.0 \\
Soya bean & 6.0 & 9.0 & 13.2 & 17.0 \\
Groundnut cake & 4.0 & 7.7 & 10.0 & 13.2 \\
Wheat offal & 30.0 & 25.7 & 22.0 & 17.0 \\
Fish meal & 3.0 & 3.0 & 3.0 & 3.0 \\
Bone meal & 3.0 & 3.0 & 3.0 & 3.0 \\
Oyster shell & 3.0 & 3.0 & 3.0 & 3.0 \\
Methionine & 0.20 & 0.20 & 0.20 & 0.20 \\
Lysine & 0.10 & 0.10 & 0.10 & 0.10 \\
Premix & 0.25 & 0.25 & 0.25 & 0.25 \\
Salt & 0.25 & 0,25 & 0.25 & 0.25 \\
Total & $\mathbf{1 0 0}$ & $\mathbf{1 0 0}$ & $\mathbf{1 0 0}$ & $\mathbf{1 0 0}$ \\
ME (Kcal/kg) & 2619.67 & 2628.71 & 2624.14 & 2626.50 \\
Crude protein (\%) & 16.09 & 18.00 & 20.03 & 22.00 \\
Crude Fibre (\%) & 4.17 & 4.14 & 4.15 & 4.10 \\
Ether Extract (\%) & 3.73 & 3.87 & 3.85 & 3.91 \\
Lysine (\%) & 0.76 & 0.86 & 0.98 & 1.08 \\
Methionine (\%) & 0.27 & 0.29 & 0.32 & 0.34 \\
\hline
\end{tabular}




\section{Data collection}

Weekly feed intake and weight gain were monitored, documented and used to determine average daily weight gain, feed intake and feed conversion ratio. When the feeding trial was 15 weeks, 2 birds per replicate were randomly selected and transferred into the metabolic cage. Adjustment period of three days was observed before feacal samples collection, the sample were later analyzed for proximate composition and nutrient digestibility analysis. At the end of 16 weeks experimental period, $2 \mathrm{ml}$ of blood per replicate was collected by severing the jugular vein of one bird per replicate into sterile bottle containing ethyl di-amine tetra-acetic acid (EDTA), to prevent blood clothing. The procedure of Jain, (1986) was followed for the blood analysis.

The meat samples of breast and thigh muscle of the birds, two samples per replicate were collected after slaughtering and sufficient bleeding. The samples collected were used for proximate analysis.

\section{Statistical analysis}

All data generated were subjected to Analysis of variance using the general linear model of SAS (2001). Means with significant difference were separated using Duncan's multiple range option of the same statistical package.

\section{Results and discussion}

Growth performance of guinea fowl fed varied levels of dietary protein

The growth performance characteristics of guinea fowl fed varying levels of dietary protein are as shown in table 2 below, the dietary treatments had significant $(\mathrm{P}<0.05)$ influence on the weight gains, daily feed intake and feed conversion ratio of the birds. Highest final weight was recorded from birds fed $18 \% \mathrm{CP}(1620.99 \mathrm{~g})$ while the least final weight was from $22 \% \mathrm{CP}$ $(1479.72 \mathrm{~g})$ and compared to the control $(16 \% \mathrm{CP})(1485.87 \mathrm{~g})$, this was in accord with Kingori et al. (2003) who report that feeding guinea fowl with excessively higher dietary protein does not result in increased weight gain. The highest weight gain from $18 \% \mathrm{Cp}$ was similar to conclusion of Le Coz- Douin (1992), that the best weight of a Guinea fowl at the period of the maximum production is attained with an amount of $18 \mathrm{~g}$ protein per $100 \mathrm{~g}$ diet. However, highest and least daily feed intake was recorded from $22 \% \mathrm{CP}$ (99.53) and $16 \%$ CP (86.37) when compared to other treatments, the variation in feed intake recorded agrees with the report of Mettle, (2009). The best feed conversion efficiency was recorded from 16\% CP (4.40) though comparable to $18 \% \mathrm{CP}(4.65)$ and $20 \% \mathrm{CP}$ (4.52). Crude protein is one of several nutritional factors that has a significant impact on the growth and health of guinea fowl; in the present study, heavier body weight of guinea fowl fed $18 \%$ CP might be the assertion for nutrient requirement of the guinea fowl. The higher feed conversion ratio from $18 \% \mathrm{CP}$ was due to the degree of increase total weight gain (Sikur et al., 2004).

Table 2: Growth performance of guinea fowl fed varied levels of dietary protein

\begin{tabular}{llllll}
\hline Parameter & $\mathbf{T}_{1}$ & $\mathbf{T}_{\mathbf{2}}$ & $\mathbf{T}_{\mathbf{3}}$ & $\mathbf{T}_{\mathbf{4}}$ & Sem \\
\hline Initial Weight $(\mathrm{g})$ & 428.90 & 433.30 & 430.17 & 435.76 & 13.24 \\
Final weight $(\mathrm{g})$ & 1526.87 & 1620.99 & 1531.55 & 1479.72 & 14.20 \\
Total weight gain $(\mathrm{g})$ & $1097.96^{\mathrm{ab}}$ & $1187.69^{\mathrm{a}}$ & $1101.38^{\mathrm{ab}}$ & $1043.96^{\mathrm{b}}$ & 19.52 \\
Daily weight gain $(\mathrm{g})$ & $19.61^{\mathrm{ab}}$ & $21.21^{\mathrm{a}}$ & $19.67^{\mathrm{ab}}$ & $18.64^{\mathrm{b}}$ & 0.35 \\
Average daily feed intake $(\mathrm{g})$ & $86.37^{\mathrm{b}}$ & $98.90^{\mathrm{ab}}$ & $88.75^{\mathrm{ab}}$ & $99.53^{\mathrm{a}}$ & 0.33 \\
Feed conversion ratio & $4.40^{\mathrm{b}}$ & $4.65^{\mathrm{b}}$ & $4.52^{\mathrm{b}}$ & $5.37^{\mathrm{a}}$ & 0.13 \\
\hline
\end{tabular}

abc Means along the same row with uncommon superscripts are significantly different $(\mathrm{P}<0.05)$

$\mathrm{T} 1-16 \% \mathrm{CP} ; \mathrm{T} 2-18 \% \mathrm{CP} ; \mathrm{T} 3-20 \% \mathrm{CP}$; $44-22 \% \mathrm{CP}$ 
Apparent nutrient digestibility of guinea fowl fed varied levels of dietary protein

There were significant $(\mathrm{P}<0.05)$ differences in the birds' nutrient digestibility (table 3 ) except for ash. Bird fed $22 \%$ dietary protein had the highest crude protein digestibility value (77.16) and the values recorded for ${ }_{16 \%}$ was comparable to $18 \%$ Least crude fibre value (10.69) from birds fed $22 \%$ dietary protein was significantly $(\mathrm{P}<0.05)$ different from $16 \%, 18 \%$ and $20 \%$ that were comparable. Significant $(\mathrm{P}<0.05)$ difference in ether extract digestibility across the treatment was recorded. The lowest value was recorded from birds fed $6 \%$ dietary protein while highest value (47.79) was obtained from $22 \%$ and was statistically $(\mathrm{P}>0.05)$ similar to $18 \%$ and $20 \%$ dietary protein. These observations simply revealed that variation in dietary crude protein responsible for different digestibility status of other nutrients.

Table 3: Apparent nutrient digestibility of guinea fowl fed varied levels of dietary protein

\begin{tabular}{llllll}
\hline $\begin{array}{l}\text { Parameter } \\
(\%)\end{array}$ & $\mathbf{T}_{\mathbf{1}}$ & $\mathbf{T}_{\mathbf{2}}$ & $\mathbf{T}_{\mathbf{3}}$ & $\mathbf{T}_{\mathbf{4}}$ & SEM \\
\hline Crude protein & $67.62^{\mathrm{b}}$ & $68.40^{\mathrm{b}}$ & $73.08^{\mathrm{ab}}$ & $77.16^{\mathrm{a}}$ & 1.50 \\
Crude fibre & $37.09^{\mathrm{a}}$ & $49.19^{\mathrm{a}}$ & $31.43^{\mathrm{a}}$ & $10.69^{\mathrm{b}}$ & 6.48 \\
Ether extract & $32.17^{\mathrm{b}}$ & $29.19^{\mathrm{ab}}$ & $42.74^{\mathrm{ab}}$ & $47.79^{\mathrm{a}}$ & 4.11 \\
Ash & 88.93 & 88.60 & 88.37 & 91.61 & 0.56 \\
Dry matter & $34.75^{\mathrm{bc}}$ & $20.88^{\mathrm{c}}$ & $43.30^{\mathrm{ab}}$ & $59.37^{\mathrm{a}}$ & 4.29 \\
\hline
\end{tabular}

${ }_{\text {abc }}$ Means along the same row with uncommon superscripts are significantly different $(\mathrm{P}<0.05)$.

T1 - 16\% CP; T2 - 18\% CP; T3 - 20\% CP; T4 - 22\% CP

Haematological parameters of guinea fowl fed varied levels of dietary protein Table 4 showed a significantly $(\mathrm{P}<0.05)$ high value of WBC of 19.53 was observed in birds placed on $20 \%$ dietary protein compared to $16.98,12.65$ and 10.83 recorded from birds fed $16 \%, 18 \%$ and $22 \%$ dietary protein respectively. This is an indication that more WBC was produced to fight pathogenic organisms that were probably present in the body of the birds as reported by Mitruka and Rawnsley, (1977). However, the reduced WBC value obtained in $\mathrm{T}_{4}$ indicates a threat to the immune system of the Guinea fowl as excessive reduction in WBC lowers the immunity (Mitruka and Rawnsley, 1977). Also 20\% dietary protein had the highest $(\mathrm{P}<0.05)$ value of platelet (185.00) compared to other treatments, the highest value of platelet obtained could be attributed to better utilization of nutrient in the diet to produce more platelet and this is in accord with the report of Jenkin et al. (2007) which further report the effect of platelet in blood clotting. The differential counts (percent) of monocytes, lymphocytes, heterophils, basophils obtained were not significantly $(\mathrm{P}>0.05)$ influenced by the dietary treatments and were within the reported range $(1.0-4 \%$, $30.0-85.0,20.0-75.0 \%, 0-4.0 \%$ and $0-$ $4.0 \%$ ) reported for guinea fowls by However, the non-significantly $(\mathrm{P}<0.05)$ variation observed in $\mathrm{Hb}$ and $\mathrm{PCV}$ among treatments indicate that treatment diets may not elicit anaemia since the values obtained between treatments were within the reference range for physiological normal guinea fowl $(8.00-17.5 \mathrm{~g} / 100 \mathrm{ml}$ and 30.00 $50.00 \%$ ) as reported by Hillyeri (2004). The $(\mathrm{P}>0.05) \quad \mathrm{RBC}$ were similar to those reported by Ifeanyi et al. (2010) who evaluated the effect of protein content on blood chemistry of guinea fowls and reported values ranging from 3.60 - 4.20. Although, guinea fowls had earlier been reported to be less susceptible to most poultry diseases (Roy and Wibberly, 1979). 


\section{Performance characteristics and meat quality assessment of guinea fowl}

Table 4: Haematological parameters of guinea fowl fed varied levels of dietary protein

\begin{tabular}{lcllll}
\hline Parameters & $\mathbf{T}_{\mathbf{1}}$ & $\mathbf{T}_{\mathbf{2}}$ & $\mathbf{T}_{\mathbf{3}}$ & $\mathbf{T}_{\mathbf{4}}$ & Sem \\
\hline Packed cell volume (\%) & 36.00 & 31.00 & 36.50 & 34.50 & 0.81 \\
Haemoglobin $(\mathrm{g} / 100 \mathrm{ml})$ & 11.90 & 13.05 & 12.15 & 11.60 & 0.29 \\
Red blood cell $\left(\mathrm{x} 10^{6} / \mathrm{mm}^{3}\right)$ & 3.67 & 3.56 & 3.91 & 3.40 & 0.41 \\
White blood cell $\left(\mathrm{x} 10^{3} / \mathrm{mm}^{3}\right)$ & $16.98^{\mathrm{b}}$ & $12.65^{\mathrm{c}}$ & $19.53^{\mathrm{a}}$ & $10.83^{\mathrm{c}}$ & 0.96 \\
Lymphocytes $(\%)$ & 65.50 & 66.00 & 63.50 & 66.00 & 1.07 \\
Heterophils (\%) & 29.00 & 31.50 & 31.50 & 28.00 & 1.06 \\
Monocyte (\%) & 2.50 & 2.50 & 3.00 & 3.00 & 0.18 \\
Eosinophil $(\%)$ & 3.00 & 1.00 & 1.50 & 3.00 & 0.13 \\
Basophil $(\%)$ & 0.16 & 0.50 & 0.50 & 3.00 & 0.13 \\
Platelet $\left(\mathrm{x} 10^{3} / \mathrm{mm}^{3}\right)$ & $122.00^{\mathrm{b}}$ & $111.00^{\mathrm{b}}$ & $185.00^{\mathrm{a}}$ & $152.00^{\mathrm{ab}}$ & 1425 \\
\hline
\end{tabular}

abc means along the same row with uncommon superscripts are significantly different $(\mathrm{P}<0.05)$.

T1 - 16\% CP; T2 - 18\% CP; T3 - 20\% CP; T4 - 22\% CP

Proximate analysis of guinea fowl meat fed varied levels of dietary protein

Table 5 showed that the value crude protein content of the thigh muscle increased $(\mathrm{P}<0.05)$ while the crude fat decreased with increased dietary protein, however no significant differences were recorded in the values for ash. Likewise, crude protein content of the breast muscle increased $(\mathrm{P}<0.05)$ while the crude fat decreased with increased dietary protein but the crude ash was not significantly $(\mathrm{P}<0.05)$ influenced by the inclusion levels. The flesh of guinea fowl has been reported to be tastier and firmer than that of chicken (Koney, 1993), this might responsible for the report that guinea fowl meat is more nutritionally desirable alternative to consumers than meat from other livestock (Santiago et al., 2007). Sharma and Singh, (2006) suggested that guinea fowl meat is preferred on account of its dark gamey taste and colour. Guinea fowls provide meat with higher protein, more essential amino acids, lower fat and lower cholesterol contents than broilers (Singh and Raheja, 1990). Proximate composition of the meat also revealed that the increasing dietary protein plays significant role on the increasing quality of the guinea fowl meat most especially in terms of crude protein and fat.

Table 5: Nutritional quality of guinea fowl meat fed varied levels of dietary protein

\begin{tabular}{llllll}
\hline Parameters $(\%)$ & $\mathbf{T}_{\mathbf{1}}$ & $\mathbf{T}_{\mathbf{2}}$ & $\mathbf{T}_{\mathbf{3}}$ & $\mathbf{T}_{\mathbf{4}}$ & Sem \\
\hline Thigh Meat & & & & & \\
Dry matter & $25.05^{\mathrm{b}}$ & $25.25^{\mathrm{ab}}$ & $25.43^{\mathrm{ab}}$ & $25.89^{\mathrm{a}}$ & 0.12 \\
Moisture Content & $74.95^{\mathrm{a}}$ & $74.48^{\mathrm{ab}}$ & $74.11^{\mathrm{b}}$ & $74.57^{\mathrm{ab}}$ & 0.11 \\
Crude Protein & $20.12^{\mathrm{c}}$ & $20.10^{\mathrm{c}}$ & $21.32^{\mathrm{b}}$ & $21.72^{\mathrm{a}}$ & 0.06 \\
Crude fat & $7.53^{\mathrm{a}}$ & $5.30^{\mathrm{b}}$ & $3.40^{\mathrm{c}}$ & $3.25^{\mathrm{c}}$ & 0.44 \\
Total ash & 1.19 & 1.47 & 0.85 & 0.95 & 0.11 \\
Breast Meat & & & & & \\
Dry matter & $27.10^{\mathrm{c}}$ & $27.63^{\mathrm{bc}}$ & $27.82^{\mathrm{b}}$ & $31.70^{\mathrm{a}}$ & 0.48 \\
Moisture Content & $68.30^{\mathrm{c}}$ & $72.90^{\mathrm{a}}$ & $72.18^{\mathrm{b}}$ & $72.37^{\mathrm{ab}}$ & 0.48 \\
Crude Protein & $25.34^{\mathrm{c}}$ & $26.16^{\mathrm{b}}$ & $26.18^{\mathrm{b}}$ & $26.23^{\mathrm{a}}$ & 0.09 \\
Crude fat & $9.00^{\mathrm{a}}$ & $8.62^{\mathrm{a}}$ & $7.46^{\mathrm{b}}$ & $4.07^{\mathrm{c}}$ & 0.51 \\
Total ash & 1.47 & 1.27 & 1.91 & 1.44 & 0.10 \\
\hline
\end{tabular}

$\overline{\text { abc }}$ means along the same row with uncommon superscripts are significantly different $(\mathrm{P}<0.05)$.

$\mathrm{T} 1-16 \% \mathrm{CP} ; \mathrm{T} 2-18 \% \mathrm{CP} ; \mathrm{T} 3-20 \% \mathrm{CP} ; \mathrm{T} 4-22 \% \mathrm{CP}$ 


\section{Conclusion}

Guinea fowl placed on $16 \%$ dietary crude protein under intensive system had the best feed conversion ratio when compared to other treatments though the birds highest relative weight was recorded from treatment with $18 \%$ dietary crude protein. The meat quality assessment of thigh muscle of guinea fowl fed varying dietary protein levels revealed that, dry matter content and crude protein content increased as the percentage dietary protein increased while the crude fat decreased. The nutrient digestibility increased as the percentage dietary protein increased while the haematological parameters were less affected with increased dietary protein. Hence for better performance, growing guinea fowl should be fed considerably with $18 \%$ dietary crude protein most especially within the age of 10 and 25 weeks.

\section{References}

Adeyemo, A. I., Oyejola, O. and Afolayan, T.A. 2006. Performance of Guinea Fowl (Numida meleagris) Fed Varying Protein Levels. J. Anim. Vet. Adv., 5(6): 519- 521.

Agwunobi, L. N. and Elpenyong, T. E. 1991. Protein and EnergyRequirements for Starting and Finishing Broiler Guinea-fowl (Numida meleagris) in the Tropics. Journal of Food Science and Agriculture. 55(2): 207-213.

Ayeni, J. S. O. 1980. The biology and utilization of the helmet guinea fowl (Numida meleagris) in Nigeria. International Journal of Poultry Science. 2(1), 41-55.

Dahouda, M., Toleba, S.S. and Youssao, A. K. I. 2017. Guinea fowl rearing constraints and flock composition under traditional management in Borgu Department, Benin. Family Poultry. 2017;17(1):3-13.
Gono, R. K., Svinurai, W. and Muzvondiwa，J. V. 2012. Constraints and opportunities to guinea fowl production in Zimbabwe: A case study of the Midlands Province, Zimbabwe. International Journal of Science and Research. 2012;2(3):236-239.

Ifeanyi, P. O., Ifeanyi, C. O. and Michael, U. I. 2010. Evaluation of Toxicological effect of leaf meal of an ethnomedicinal plant. Blood chemistry of pubertal Chinchilla Rabbit doe. Report and Opinion: 2(2).

Jain, N. C. 1986. Schalm Veterinary Haematology. 4th Edn., Lea and Febiger, Philadelphia, USA.

Jenkins, Henry, Ravi Purushotma, Katie Clinton, Margaret Weigel, and Alice J. Robison. D. (2007) Confronting the $\mathrm{C}$ bhallenges of Participatory Culture: Media Education for the $21 \mathrm{st}$ Century. Chicago, Illinois: The McArthur Foundation.

Kingori, A. M., Tutoek, J. K., Muimri, H. K. and Wachira, A. M. 2003. Protein requirements of growing indigenous chicken during the 1421 weeks growing period. South African Journal of Animal Science. 33(2): Pp 78-82.

Koney, E. B. N. 1993. Poultry health and production. Advert press. Osu, Accra. $185 \mathrm{Pp}$.

Mettle, S. S. 2009. The effects of a cassava peel and blood mixture (Blocassap) on the growth performance of starter-grower pigs. MSc. Thesis. Faculty of Agriculture, Department of Animal Science, Kwame Nkrumah University of Science and Technology, Kumasi, Ghana.

Mitruka, B. M. and Rawnsley, H. M. 1977. Clinical biochemical and Haematological references value in 
normal experimental animals. Masson Pub USA Inc. N. V. Pp. 2184.

Moreki, J. C. and Seabo, D. 2012. Guinea fowl production in Botswana. Journal of World's Poultry Research, 2(1):1-4.

Roy, D. E. and Wibberley, E. H. A. 1979. Guinea fowl. A Tropical agriculture handbook. UK. The Comelet Press.

Santiago, H. L., Diaz, V. and Rodriguez, A. A. 2007. Processing yields, meat quality attributes and nutrient composition of diverging genotypes of guinea fowl (Numida meleagris) broiler reared on various planes of nutrition in a tropical environment. Animal Science 13 Pp. 236-238.

Sarica, M., Camci, Ö. and Selęuk, E. 2003. Quail, pheasant, pigeon, guinea fowl and Ostrich farming. Turkey International Journal of Animal Science, 4: 129-144.
Sharma, D. and Singh, H. 2006. Future research priorities in guinea fowl breeding and Genetics, Poultry Research Priorities, 22-30.

Sikur, V. R., Robinson, F. E., Korver, D. R., Renema, R. A. and Zuidhof, M. J. 2004. Effect of nutrient density on growth and carcass traits in fast and slow feathering female turkeys. Poult. Sci. 83:1507-1517.

Singh, H. and Raheja, K. L. 1990. Genetic estimates of cholesterol and highdensity lipid components in indigenous guinea fowl serum. Proceeding of xii annual conference and symposium of Indian poultry science association. Bombay Veterinary College, Bombay, India.

Statistical Analysis System 2001. User's Guide: Statistics, Version 8.2. SAS Institute, NC, USA.

Received: $19^{\text {th }}$ May, 2021 Accepted: $15^{\text {th }}$ August, 2021 